\title{
Immunophenotypic characterisation of acute leukaemia after polycythemia vera
}

\author{
J M Hernández, A Orfao, M González, B Cuesta, M C López-Berges, M C Cañizo, \\ J Ciudad, J F San Miguel
}

\begin{abstract}
Aims-To analyze the immunophenotype of blast cells in patients with acute leukaemia after polycythemia vera, together with the most relevant clinical and haematological disease characteristics.
\end{abstract}

Methods-The immunophenotype was analysed in nine patients by immunofluorescence flow cytometry using a panel of 15 monoclonal antibodies. The DNA content of blast cells was determined using Vindelov's technique.

Results-The most relevant clinical and haematological disease characteristics included: the presence of enlarged spleen and liver by $56 \%$ and $67 \%$, respectively; a moderate degree of leucocytosis with thrombocytopenia while haemoglobin was normal in $50 \%$ of patients. All patients received alkylating agents or hydroxyurea, or both. Interestingly, the chronic phase in patients receiving this latter drug was shorter. All cases showed a myeloid phenotype, four of them reactive only to early myeloid antigens (CD13/33); in the remaining cases the blast cells displayed granulomonocytic (CD14+, CD15+), erythroid $(\mathrm{CD} 71+++)$, or megakaryocytic (CD61 + , CD41 +) markers. Coexpression of lymphoid related antigens (CD7, TdT, or CD19) was also detected. The morphological assessment of blast cells agreed with the immunophenotyping in five out of the nine cases. Blast cells from all six patients analysed displayed a diploid DNA content and the proportion of Sphase cells ranged from $0.4 \%$ to $4 \%$.

Conclusions-These findings suggest a pluripotential stem cell with myeloid commitment as the target cell of acute leukaemia after polycythemia vera.

(F Clin Pathol 1993;46:668-671)

Polycythemia vera (PV) is a clonal disorder in which all hemopoietic precursor cell lines may be affected. ${ }^{1}$ Transformation into acute leukaemia may be either a part of the natural course of the disease-about $1 \%$ of patients treated with phlebotomy alone develop acute leukaemia ${ }^{2}$ - or secondary to the treatment used during the chronic phase. Accordingly, the use of radioactive phosphorus has been associated with an incidence of acute transformations of $11 \% .^{3}$ Moreover, the
Polycythemia Vera Study Group found an increased incidence of acute leukaemia in patients who had previously been treated with alkylating agents, this being 2.3 and 13 times higher than that of patients treated with radioactive phosphorus or with phlebotomy alone. ${ }^{4}$ It was initially suggested that hydroxyurea had less of a leukaemic effect, although further studies have shown that this agent is also related to an increase in the incidence of acute leukaemia in patients with polycythemia vera ${ }^{5}$ of up to 3.5 times more than in other series. ${ }^{6}$ The clinical and haematological characteristics of acute leukaemia after polycythemia vera have been analysed by several groups, ${ }^{27-10}$ but no studies in the immunophenotypic features of the blast cells in leukaemic transformation have been performed.

The aim of the present study was to characterise the immunophenotype of proliferating cells in acute leukaemia after a polycythemia vera together with the most relevant clinical and hematological disease characteristics, including the DNA content of blast cells.

\section{Methods}

Between 1988 and 1992, nine adult patients with acute leukaemia after polycythemia vera were studied at the University Hospital of Salamanca. The diagnosis of polycythemia vera was based on the criteria proposed by the Polycythemia Vera Study Group. ${ }^{11}$ Diagnosis of acute leukaemia was established when more than $30 \%$ blast cells were detected in either bone marrow or peripheral blood, or both. ${ }^{12}$

Peripheral blood and bone marrow smears were stained with May-Grünwald-Giemsa and cytochemical methods for peroxidase, non-specific esterases (naphtol AS-D acetate esterase or $a$ naphthyl acetate esterase, both with and without sodium fluoride inhibition), periodic acid Schiff and $a$ naphthyl butyrate esterase.

\section{IMMUNOLOGICAL PHENOTYPE}

In all nine patients mononuclear cells from the moment of diagnosis of acute transformation were isolated from peripheral blood by Ficoll-Hypaque density gradient centrifugation. The cells were analysed by indirect immunoflourescence with a terminal deoxynucleotidyl transferase (TdT) heteroantiserum (Supertechs, Bethesda, Maryland), and a panel of monoclonal antibodies whose reactivity and specificity have been described. ${ }^{13}$ \\ 20 January 1993
}


For early myeloid cells, the following monoclonal antibodies were used: My9 (CD33) and My7 (CD13); for granulocytic lineage, VIMD5 and FMC10 (CD15); for monocytic lineage, FMC17 and leuM3 (CD14); for megakaryoblasts, J15 (CD41, anti GPIIb/IIIa), C17 (CD61, anti GPIIIa), FMC25 (CD42a, anti GPIX), and AN51 (CD42b, anti GPIb); for erythroid lineage, LICR LON·R10 (anti-glycophorin A); for precursor cells, GRB1 (anti-HLA-DR), FMC56 (CD9); and for lymphoid lineage, B4 and leu12 (CD19), B1 (CD20), 3A1 (CD7), and J5 (CD10).

To minimise non-specific $F c$ receptor binding, the cells were incubated at room temperature for 15 minutes with avidin-biotin serum to block the Fc receptor and washed in a buffer containing phosphate buffered salinebovine serum albumin-avidin-biotin serum. In all experiments, as a negative control, we also omitted the first antibody and used irrelevant isotype matched monoclonal antibodies. Cells were analysed either by immunofluorescence microscopy (Leitz Ortholux) or flow cytometry (FACScan BD, Mountain View, California, USA). For the assessment of a lineage, a minimum of $15 \%$ blast cells positive for one or more of the specific monoclonal antibodies was required. ${ }^{14} 15$ The presence of either one or two cell populations was assessed by appropriate individual dual stainings, as described. ${ }^{1316}$

\section{DNA CELL CYCLE}

DNA measurements were performed on isolated nuclei from six patients using Vindelov et al's technique. ${ }^{1617}$ Briefly, $1 \times 10^{6}$ leucocytes from ammonium chloride-lysed whole blood were washed and resuspended in $200 \mu \mathrm{l}$ of a sodium citrate buffer. Cells were then incubated for 10 minutes at room temperature with $1.8 \mathrm{ml}$ of a solution A containing a detergent (Nonidet $\mathrm{p} 40$ ) and trypsin $(30 \mathrm{mg} / \mathrm{l})$. Afterwards $1.5 \mathrm{ml}$ of a solution $B$ containing RNAase $(100 \mathrm{mg} / \mathrm{l})$ and a trypsin inhibitor $(500 \mathrm{mg} / \mathrm{ml})$ were added for another 10 minute incubation period at room temperature. Finally, a third incubation at room temperature for at least 15 minutes in the dark was performed after adding $1.5 \mathrm{ml}$ of a third cytrate buffer solution containing propidium iodide $(4.6 \mathrm{mg} / \mathrm{l})$ to complete a final volume of $5 \mathrm{ml}$. A duplicate including $50 \mu \mathrm{l}$ of a normal sex matched lysed whole blood sample was used to assess the existence of DNA aneuploidy. Measurements were made within one hour in a FACScan flow cytometer (Becton Dickinson) equipped with a doublet discrimination module for at least $\mathbf{5 0 0 0}$ nuclei/sample. The electronics of the instrument were adjusted with chicken erythrocytes so that the modal channel for the $G_{0} / G_{1}$ human diploid nuclei was 250 (1023 total channels). Analysis of the DNA histograms to calculate the proportion of cells with a DNA amount corresponding to the various parts of the cell cycle was performed using the RFIT model included in the CellFit software program (Becton Dickinson). The mean (SD) coefficient of variation of the $G_{0} / G_{1}$ phase peak was $2.5(0.9) \%$. Absolute peripheral blood S-phase leucocyte counts were calculated by multiplying the percentage of peripheral blood S-phase cells by the white cell count of each patient.

\section{Results}

The most relevant clinicobiological features of the nine secondary acute leukaemias analysed are summarised in table 1 . The interval from the diagnosis of polycythemia vera to the acute transformation was long, ranging from 36 to 172 months (median seven years). All but one out of the nine patients had been treated before. Six patients received hydroxyurea either alone (three cases) or in combination with alkylating agents (two cases), or with radioactive phosphorus (one case). The other three patients were treated with ${ }^{32} \mathrm{P}$ alone (one case), busulfan (one case), or both (one case). The median duration of the chronic phase was shorter in patients receiving hydroxyurea alone (36, 47 , and 91 months, respectively) than in those treated with ${ }^{32} \mathrm{P}(82,120$, and 132 months, respectively).

Most patients were male (six out of nine) and older (68 years). The most common clinical findings at presentation of acute leukaemia were systemic symptoms $56 \%$ of cases (table 1), together with hepatomegaly $(67 \%)$ and splenomegaly (56\%). The spleen was very enlarged in four out the nine patients. Four cases presented a normal or even increased haemoglobin concentration. These four cases showed leucocytosis. Six

Table 1 Clinical and biological characteristics of acute leukaemia after polycythemia vera

\begin{tabular}{|c|c|c|c|c|c|c|c|c|}
\hline Reference & $\begin{array}{l}\text { Chronic phase } \\
\text { duration } \\
\text { (months) }\end{array}$ & Age & $\begin{array}{l}\text { Sex } \\
(\% M)\end{array}$ & $\begin{array}{l}H B \\
(g / l)\end{array}$ & $\begin{array}{l}\text { Leucocytes } \\
\left(\times 10^{9} / 1\right)\end{array}$ & $\begin{array}{l}\text { Platelets } \\
\left(\times 10^{9} / 1\right)\end{array}$ & $\begin{array}{l}\text { Bone marrow } \\
\text { blasts } \\
(\%)\end{array}$ & $\begin{array}{l}\text { Survival } \\
\text { (weeks) }\end{array}$ \\
\hline $\begin{array}{l}\text { Rosenthal } \\
(n=9)^{9}\end{array}$ & $\begin{array}{l}120 \\
(30-240)\end{array}$ & $\begin{array}{l}65 \\
(42-82)\end{array}$ & 62 & $\begin{array}{l}0 \cdot 81 \\
(6-15)\end{array}$ & $\begin{array}{l}59 \\
(10-277)\end{array}$ & $\begin{array}{l}42 \\
(3-206)\end{array}$ & non referred & $\begin{array}{l}3 \\
(1-52)\end{array}$ \\
\hline $\begin{array}{l}\text { Weinfeld } \\
\quad(n=8)^{7}\end{array}$ & $\begin{array}{l}102 \\
(42-138)\end{array}$ & $\begin{array}{l}70 \\
(54-75)\end{array}$ & 37 & $\begin{array}{l}0 \cdot 82 \\
(6-11)\end{array}$ & $\begin{array}{l}4 \\
(1-129)\end{array}$ & $\begin{array}{l}32 \\
(13-48)\end{array}$ & non referred & $\begin{array}{l}10 \\
(0-33)\end{array}$ \\
\hline $\begin{array}{l}\text { Donovan } \\
\quad(n=13)^{10}\end{array}$ & $\begin{array}{l}72 \\
(12-132)\end{array}$ & $\begin{array}{l}69 \\
(54-79)\end{array}$ & 54 & non referred & $\begin{array}{l}11 \\
(1-170)\end{array}$ & non referred & $\begin{array}{l}60 \\
(25-90)\end{array}$ & $\begin{array}{l}4 \\
(0-52)\end{array}$ \\
\hline $\begin{array}{l}\text { Najean } \\
\quad(n=16)^{9}\end{array}$ & 120 & 56 & 71 & $\begin{array}{l}0.92 \\
(5-19)\end{array}$ & $\begin{array}{l}13 \\
(1-241)\end{array}$ & $\begin{array}{l}130 \\
(15-640)\end{array}$ & $\begin{array}{l}50 \\
(38-85)\end{array}$ & $\begin{array}{l}<12 \\
(1-72)\end{array}$ \\
\hline $\begin{array}{l}\text { Present } \\
\text { series } \\
(n=9)\end{array}$ & $\begin{array}{l}82 \\
(36-132)\end{array}$ & $\begin{array}{l}71 \\
(54-76)\end{array}$ & 67 & $\begin{array}{l}0 \cdot 111 \\
(7-17)\end{array}$ & $\frac{13}{(2-47)}$ & $\begin{array}{l}54 \\
(23-216)\end{array}$ & $\stackrel{52}{(31-90)}$ & $\begin{array}{l}7 \\
(2-34)\end{array}$ \\
\hline
\end{tabular}

Results expressed as median (range) or percentage of positive cases. 
Table 2 Immunophenotypic and morphological features of acute leukaemia after polycythemia vera

\begin{tabular}{|c|c|c|}
\hline Immunophenotype & $\begin{array}{l}\text { No of } \\
\text { patients }\end{array}$ & $\begin{array}{l}\text { Morphology and } \\
\text { Cytochemistry (FAB) }\end{array}$ \\
\hline $\begin{array}{l}\text { Myeloblastic } \\
\text { (CD13/33 +, CD15-, CD14-)† }\end{array}$ & 4 & $\begin{array}{l}\text { Myeloid-undifferentiated (M0) } \\
\text { MB/MO/ER } \\
\text { Myelomonocytic (M4) (two cases) }\end{array}$ \\
\hline $\begin{array}{l}\text { Granulomonocytic } \\
\text { (CD13/33+, CD15+, CD14+) }\end{array}$ & 1 & Myelomonocytic (M4) \\
\hline $\begin{array}{l}\text { Erythroid } \\
\text { (CD13/33 +, CD71 +, Antiglicoph.-) } \ddagger\end{array}$ & 1 & Erythroid (M6) \\
\hline $\begin{array}{l}\text { Megakaryocytic } \\
\text { CD13/33+, CD15+, CD41 +, CD42a + +† } \\
\text { CD13/33+, CD15+, CD14+, CD61 + } \\
\text { CD13/33+, CD15-, CD61 + }\end{array}$ & $\begin{array}{l}1 \\
1 \\
1\end{array}$ & $\begin{array}{l}\text { Megakaryocytic (M7) } \\
\text { Myeloblastic (M2) } \\
\text { Megakaryocytic (M7) }\end{array}$ \\
\hline
\end{tabular}

patients, however, displayed thrombocytopenia (table 1). Because of their advanced age, four patients received only supportive treatment. Three patients were treated with aggressive chemotherapy (anthracycline and ara-c) and the other two with low doses of ara-c. Only one patient treated with low doses of ara-c achieved complete remission. The median survival of the acute phase in the whole series was eight weeks, ranging from two to 16 weeks.

The immunophenotypic characteristics of the nine patients studied are shown in table 2 .

All cases showed a myeloid phenotype, four of them displaying reactivity only for early myeloid antigens (CD13/33), while in the remaining cases the blast cells displayed either granulomonocytic (CD14+, CD15+) or erythroid (CD71 +++ ) antigenic differentiation.

In three out of the nine acute leukaemias a megakaryocytic component was found; all of these three cases were also $\mathrm{CD} 13+$ or CD33 + (table 2). Five out of the nine cases expressed lymphoid related antigens: expression of CD7 was detected in three cases, while either $\mathrm{TdT}+$ and CD19+ blast cells were present in another two patients.

Because the FAB criteria cannot be properly applied to secondary acute leukaemias, ${ }^{19}$ a descriptive morphological classification was used, assigning the blast cells to one of the following possible cell lineages: myeloblastic, monocytic, erythroid and megakaryocytic (table 2). Concordant findings with the immunophenotype of blast cells were achieved in five out of the nine cases. The discrepancies involved three patients with a myeloblastic phenotype, who were morphologically classified as having myelomonocytic

Table 3 Cell cycle and immunophenotype in acute leukaemia after polycythemia vera

\begin{tabular}{lllll}
\hline Case No & DNA index & $\begin{array}{l}\text { S-phase } \\
(\%)\end{array}$ & $\begin{array}{l}\text { S-phase } \\
(\text { absolute count) } \\
\left(10^{9} / 1\right)\end{array}$ & Immunophenotype \\
\hline 4 & $1 \cdot 00$ & $0 \cdot 4$ & $0 \cdot 10$ & Myeloblastic \\
5 & 1.00 & $2 \cdot 8$ & $0 \cdot 10$ & Myeloblastic (CD7+) \\
6 & 1.00 & 1 & $0 \cdot 28$ & Myeloblastic (TdT+) \\
7 & 1.00 & 4 & $0 \cdot 07$ & Myeloblastic (CD19+) \\
8 & 1.00 & 25 & $2 \cdot 30$ & Erythroid (CD7+) \\
9 & 1.00 & 2 & $0 \cdot 06$ & Mixed myeloid \\
\hline
\end{tabular}

The median of the variation coefficient was $2 \cdot 7$ (range 0.9 to $3 \cdot 3$ ). (two cases) or erythroid (one case) leukaemia, and one case with megakaryocytic antigens in which megakaryoblasts were not identified by morphology.

Blast cells from all six patients analysed displayed a diploid DNA content; the proportion of S-phase cells ranged from $0.4 \%$ to $4 \%$ (mean (SD) value of $5.9 \%(9.5) \%$ ) with absolute counts of $0.5(0.9) \times 10 \%$ (range 0.06 to $\left.2.3 \times 10^{9} / 1\right)$. Although the number of cases analysed is relatively small, those cases expressing lymphoid related markers may display a higher proliferation rate: $8.2(11.3) \% v$ $1.2(1.1) \%$ and $0.7(1.1) \times 10 \%$ v 0.08 $(0.03) \times 10^{9} / 1$ (table 3$)$.

\section{Discussion}

Several studies have been devoted to analysing the clinical and haematological characteristics of the acute transformation in polycythemia vera. ${ }^{2196-9}$ By contrast, the information about the immunophenotypic features of these acute leukaemias is based on single case reports; to the best of our knowledge this is the first series of patients in which the DNA cycle has been analysed. All patients in whom the presence of DNA aneuploidy was investigated displayed a diploid DNA content. These data agree with previous studies that have shown a low incidence of hyperdiploid karyotypes in acute leukaemia after polycythemia vera. ${ }^{20}{ }^{21}$ The cell cycle distribution of peripheral blood blast cells in acute leukaemias after polycythemia vera varies, very much like that of the de novo acute myelogenous leukaemia. ${ }^{22}$ Interestingly, we observed that those cases expressing lymphoid related antigens had a higher number of S-phase cells.

The clinical features of our patients were consistent with those of the series of acute leukaemia after previous polycythemia vera, with a short survival (table 1). ${ }^{6-10}$ As in our study, most of the patients had received prior treatment with alkylating agents, radioactive phosphorus, or hydroxyurea. ${ }^{7-10}$ It has still not been determined whether hydroxyurea is less leukaemogenic than other agents. ${ }^{2}$ The patients treated with hydroxyurea alone had a shorter chronic phase than those treated only with alkylating agents or radioactive phosphorus. Preliminary studies suggest that the use of hydroxyurea and multiple therapies induce more leukaemic transformations than alkylating agents alone. ${ }^{63}$ Nevertheless, randomised studies should be conducted, such as the one from the Polycythemia Vera Study Group-08, to determine the potential leukaemogenic role of this agent in the development of acute leukaemia during the clinical course of polycythemia vera.

Using a morphological and cytochemical approach previous studies have shown that acute leukaemias after polycythemia vera are generally myeloblastic, ${ }^{7-10}$ although in some case reports the existence of erythroid ${ }^{79}$ or lymphoid ${ }^{24-26}$ transformations have been suspected on morphological grounds. Our immunological data confirm the view that 
although a typical early myeloid phenotype is the one most commonly detected, ${ }^{27}$ the expression of markers associated with other cell lineages, such as megakaryocytic (not previously described in these acute transformations) and erythroid, may also be involved in these leukaemias. Despite the relatively good correlation between the morphological and immunological features of blast cells, the present data suggest that the diagnosis and classification of these leukaemias is better achieved by a combined morphological, cytochemical, and immunological approach.

The relatively high prevalence of megakaryocytic activity (33\%) should be noted. These results are similar to those previously observed in the acute transformations of other myeloproliferative disorders, such as chronic myelogenous leukaemia, ${ }^{14}{ }^{28}$ or idiopathic myelofibrosis, ${ }^{15}$ and suggest that a pluripotent myeloid committed stem cell may be the target cell for these leukaemias. In contrast, the incidence of erythroid transformations is less than would be expected from the proliferating cells in the chronic phase of the disease. Until now, only three cases of lymphoid transformations of polycythemia vera have been reported; the immunological criteria used to assess the lymphoid phenotype, however, were not clearly defined. ${ }^{24-26}$ Interestingly, although we did not observe pure lymphoid transformations, we detected quite a high incidence of aberrant lymphoid related markers in these acute leukaemias. The proportion of $\mathrm{TdT}+(11 \%)$ or CD19+ $(11 \%)$ and the CD7 + (25\%) cases was similar to that observed in de novo acute myelogenous leukaemia. ${ }^{2930}$ The expression of these "aberrant" markers may suggest that the target cell of these transformations is an early progenitor cell that, although committed to myeloid lineage differentiation, does retain some early lymphoid related markers.

This work was supported by a grant from the Consejeria de Cultura. Junta de Castilla-León, España (12/0491).

1 Adamson JW, Fialkow PJ, Murphy S, et al. Polycythemia vera: stem-cell and probable clonal origin of the disease. N Engl f Med 1976;295:913-16.

2 Landaw SA. Acute leukaemia in polycythemia vera. Semin Hematol 1986:23:156-65.

3 Modan B, Lilienfeld AM. Polycythemia vera and leukaemia - the role of radiation treatment: a study of 1222 patients. Medicine (Baltimore) 1965;44:305-44.

4 Berk PD, Goldberg JD, Silverstein MN, et al. Increased incidence of acute leukaemia in polycythemia vera asso-
ciated with chlorambucil therapy. $N$ Engl $f \mathrm{Med} 1981$; 304:441-7.

5 Kaplan ME, Mack K, Goldberg JD, et al. Long-term management of polycythemia vera with hydroxyurea: a progress report. Semin Hematol 1987;23:167-71.

6 Nand S, Messmore H, Fisher SG, et al. Leukemic transformation in polycythemia vera: analysis of risks factors. Am $\mathcal{f}$ Hematol 1990;34:32-6.
7 Weinfeld A, Westin J, Ridell B, Swolin B. Polycythemia vera terminating in acute leukaemia. A clinical, cytogenetic and morphologic study in 8 patients treated with alkylating agents. Scand $\mathcal{f}$ Haematol 1977;19:255-72.

8 Rosenthal DS, Moloney WC. Occurrence of acute leukaemia in myeloproliferative disorders. $\mathrm{Br} \mathcal{F} \mathrm{Haematol}$ leukaemia in mye

9 Najean Y, Deschamps A, Dresch A, et al. Acute leukaemia and myelodysplasia in polycythemia vera. Cancer 1988 ; 61:89-95

10 Donovan PB, Landaw SA, Dresch C, et al. Resistance to therapy of acute leukaemia developing in the course of polycythemia vera. Nouv Rev Fr Hematol 1981;23: $187-92$.

11 Wasserman LR. The treatment of polycythemia vera. Semin Hematol 1976;13:57-78.

12 San Miguel JF, Tavares de Castro J, Matutes E, et al. Characterization of blast cells in chronic granulocytic leukaemia in transformation, acute myelofibrosis and undifferentiated leukaemia. $\mathrm{Br} \mathcal{f}$ Haematol 1985;59: undifferentis

13 San Miguel JF, Hernández JM, González-Sarmiento R, et al. Acute leukaemia following a primary myelodysplastic syndrome: immunophenotypic, genotypic and clinical characteristics. Blood 1991;78:768-74

14 Bettelheim $P$, Lutz D, Majdic O, et al. Cell lineage heterogeneity in blast crisis of chronic myeloid leukaemia. $\mathrm{Br} \mathcal{F}$ Haematol 1985;59:395-409.

15 Hernández JM, San Miguel JF, González $M$, et al. Development of acute leukaemia after idiopathic myelofibrosis. $\mathcal{F}$ Clin Pathol 1992;45:427-30.

16 San Miguel JF, González M, Cañizo MC, et al. Surface marker analysis in acute myloid leukaemia and correlation with FAB classification. Br $\mathcal{f}$ Haematol 1986;64: 547-60.

17 Vindelov LL, Christensen IJ, Nissen NI. A detergenttrypsin method for the preparation of nuclei for flow trypsin method for the preparation of nuclei for
cytometric DNA analysis. Cytometry 1983;3:323-7.

18 Orfao A, Ciudad J, González M, et al. Prognostic value of S-phase white blood cell count in B-cell chronic lymphocytic leukemia. Leukemia 1992;6:47-51.

19 Bennet JM, Catovsky D, Daniel MT, et al. Proposals for the classification of the acute leukaemias. Br $\mathcal{F}$ Haematol 1976;33:451-8.

20 Swolin B, Weinfeld A, Westin J. A prospective long-term cytogenetic study in Polycythemia Vera in relation to treatment and clinical course. Blood 1988;72:386-95.

21 Mertens F, Johanson B, Heim S, et al. Karyotypic patterns in chronic myeloproliferative disorders: report of 74 cases and review of the literature. Leukaemia 1991;5: cases and 214 .

22 Orfao A, Vidriales B, González M, López-Berges MC Cañizo MC, San Miguel JF. Diagnostic and prognostic importance of immunophenotyping in adults with acute myeloid leukemia. In: Ludwig WD, Thiel E, Eds. Recent results in cancer research. Recent advances in tumor cell biology of acute leukemias: impact on clinical diagnosis and therapy Berlin: Springer Verlag, 1993

23 Ellis JT, Peterson P, Geller SA, Rappaport. Studies of the bone marrow in polycythemia vera and the evolution of myelofibrosis and second hematologic malignancies. Semin Hematol 1986;23:144-55.

24 Hoffman R, Estre S, Kopel S, et al: Lymphoblastic-like leukemic transformation of polycythemia vera. Ann Intern Med 1978;89:71.

25 Toh BT, Gregory SA, Knospe WH. Acute leukaemia following treatment of polycythemia vera and essential thrombocythem

26 Anastasi J, Pettenati MJ, Le-Beau MM, et al. Acute lymphoblastic leukaemia in a patient with longstanding polycythemia vera: cytogenetic analysis reveals two distinct abnormal clones. Am $\mathcal{f}$ Hematol 1988;29:33-7.

27 Cervantes F, Tassies D, Salgado C, et al. Acute transformation in nonleukemic chronic myeloproliferative disorders: actuarial probability and main characteristics in series of 218 patients. Acta Hematol 1991;85:124-7.

28 Hernández JM, González-Sarmiento R, Martín C, et al. Immunophenotypic, genomic and clinical characteristics of blast crisis of chronic myelogenous leukaemia. $\mathrm{Br} f$ Haematol 1991;79:408-11.

29 Parreira A, Pombo de Oliveira MS, Matutes E, et al. Terminal deoxynucleotidyl transferase positive acute myeloid leukaemia: an association with immature myeloid leukaemia: an association with immature

30 Urbano-Ispizua A, Matutes E, Villamor N, et al. The value of detecting surface and cytoplasmic antigens in acute myeloid leukaemia. $\mathrm{Br} \mathcal{F}$ Haematol 1992;81 178-83. 